\title{
CHARACTERISATION OF AN IN VITRO AGED CELL CULTURE MODEL
}

\author{
MARKO BUNC ${ }^{1}$, SARA M HANNING ${ }^{2}$, JOSE M PRIETO ${ }^{3}$, JULIJANA KRISTL ${ }^{1}$, MINE ORLU ${ }^{3 *}$ \\ ${ }^{1}$ University of Ljubljana, Faculty of Pharmacy, Aškerčeva cesta 7, 1000 Ljubljana, Slovenia \\ ${ }^{2}$ University of Auckland, School of Pharmacy, Private Bag 92019, Auckland 1142, New Zealand \\ ${ }^{3}$ University College London, UCL School of Pharmacy, 29-39 Brunswick Square, London WC1N 1AX, United Kingdom
}

*corresponding author:m.orlu@ucl.ac.uk

Manuscript received: October 2018

\begin{abstract}
The present study aims to provide a detailed protocol to obtain an aged cell culture model, which is conveniently characterised in terms of morphology, metabolism, and key biochemical markers of senescence. Commercial Human Dermal Fibroblasts (HDF) (67-year-old female Asian donor) were cultured over a span of 35 passages to determine at what passages they express the phenotypes found in vivo in the geriatric population. The growth rate and density (counting, Trypan Blue) at confluence declined 4- and 3-fold, respectively. During 15 passages in vitro ageing the fibroblast metabolic capacity (XTT) was heavily reduced (by 75\%), while conversely the content of cellular proteins (SRB) slightly increased (2 fold). Senescent cells (SA- $\beta$-gal positive) were continuously emerging from 0 to $20 \%$. Freezing/thawing at this stage restored metabolic performance to original values which declined at a similar rate as before. Passages 5 - 10 of our selected aged HDFs were found to mimic in vivo tissue of older adults to the greatest extent.
\end{abstract}

\section{Rezumat}

Scopul studiului este de a furniza un protocol de obținere al unui model de cultură celulară senescentă, caracterizat în mod convenabil din punct de vedere morfologic, metabolic și al expresiei markerilor biochimici caracteristici senescenței. Fibroblaste dermice umane disponibile comercial (HDF) (donator asiatic de sex feminin de 67 de ani) au fost cultivate într-o succesiune de 35 de pasaje pentru a determina cu exactitate când se exprimă fenotipurile in vivo în populaţia geriatrică. Rata de creștere și densitatea la confluență au scăzut de 4 ori și, respectiv, de 3 ori. Pe parcursul a 15 pasaje, capacitatea metabolică a fibroblastelor a fost redusă puternic (cu 75\%), în timp ce conținutul de proteine celulare a crescut ușor (de 2 ori). Celulele senescente (SA- $\beta$-gal pozitive) au apărut în mod continuu cu până la $20 \%$. Înghețarea/dezghețarea în această etapă au restabilit performanța metabolică la valorile iniţiale, care au scăzut la o rată similară cu cea inițială. S-a constatat că pasajele 5 - 10 ale celulelor îmbătrânite mimează într-o mare măsură țesutul in vivo al adulților în vârstă.

Keywords: aged cell culture, senescence, in vitro assay

\section{Introduction}

The world population is undergoing a demographic shift and life expectancy is continuously increasing [1]. Consequently, older adults (i.e. aged $>65$ ) are the group consuming the majority of medicines [2]. Along with various disabilities and illnesses elderly patients might be suffering from, they represent a very heterogeneous population [1]. The process of ageing impacts on a transient loss of physiological, tissue, cellular, and molecular functionality of cells and tissues, resulting in altered kinetics of the administered drugs, which can be expressed to different extents [3]. However, not all medicines are tailored to their needs specifically [2]. In recent years, formulations suitable for geriatric subpopulations have been gaining more attention [4-7]. In the design of drug delivery systems, changes that result from ageing at a cellular level are often not considered [3].

Conventional safety and efficacy test models, such as animal experiments or static in vitro systems, ranging from classic two-dimensional monolayer cell culture models to newer biodynamic imaging in threedimensional cell or tissue models, and "organotypic slice-on-chop" procedures do not imitate relevant features of these patients yet [8-10]. Therefore, with novel formulations being developed in particular for older patients in the era of personalized medicine, the need for a new cell culture model mimicking as closely as possible physiological conditions of the aged population was acknowledged. Such a model was hypothesised to be useful during drug discovery and preclinical studies to determine cytotoxicity and efficacy of active pharmaceutical ingredients and formulations.

The aim of this study is to investigate how it can be replicated in vitro the age-related changes that occur in vivo. The changes that occur in human cells progressively are almost impossible to mimic in in vivo studies but is reasonable to follow molecular events in cellular culture [11]. It is generally accepted that somatic, or at least proliferating cells, preserve the ability to undergo cellular senescence, which is defined as a permanent proliferative cell cycle arrest 
that is resistant to growth factors and other signals that induce cell proliferation [12]. Human cells are capable of roughly 50 population doublings only. This phenomenon, known as the 'Hayflick limit', occurs when an entire cell population enters senescence $[11,13]$, where cell "reprogramming" finalises not only in permanent growth arrest, but also in changed morphology and function [12]. Apart from an inability to divide in optimal environmental conditions, senescent cells are larger in size, have different morphology, altered gene expression and acquire the senescence-associated secretory phenotype (SASP) [14-17]. Senescent cells are often found in the tissue of elderly, while very rarely in young tissue $[14,18]$. It is assumed that senescent cells negatively impact neighbouring cells through their SASP, thus contributing to higher susceptibility to pathological changes [13, 14, 18, 19].

Among different types of cells, primary cells preserve most of the characteristics from the tissue when grown in vitro [20]. Immortalised cell lines undergo several mutations to escape senescence leading to a significant change in their phenotype and were thus deemed inappropriate for our study. Fibroblasts were the first cells successfully cultured in laboratory and are today the most extensively used cell culture for research involving cell ageing $[13,15]$ and interactions with delivery systems [21, 22]. Additionally, they are extremely easy to culture in vitro $[23,24]$, thus being appropriate for any cell laboratory. Based on their wide availability and long history of use, human dermal fibroblasts were selected for the development of the presented aged cell culture model.

To our knowledge, no attempt to develop an aged cell culture model for preliminary safety screening of drug delivery systems or active pharmaceutical ingredients has been described to date. This study aimed to explore if an aged cell culture model may mimic the characteristics of older people by investigating the effect of cell culture age on cell morphology, maximal growth rate, density at confluence, occurrence of senescent cells and cell viability.

\section{Materials and Methods}

\section{Materials}

Human Dermal Fibroblasts (HDF) from a 67-year-old female Asian donor were obtained from Life Tech. (Cat. No. C0135C, Lot 771555) (Carlsbad, CA, USA). Cell culture media and supplements were supplied by Sigma-Aldrich (St. Louis, MO, USA). 2,3-Bis(2-
methoxy-4-nitro-5-sulfophenyl)-2H-tetrazolium-5carboxanilide inner salt (XTT, 90\%) was supplied by Alfa Aesar (Karlsruhe, Germany). All other reagents were cell culture grade and from Sigma-Aldrich ${ }^{\circledR}$ (St. Louis, MO, USA).

Cell culture

HDFs were cultured as adherent monolayers in humidified air with $5 \% \mathrm{CO}_{2}$ and $37^{\circ} \mathrm{C}$ in Dulbecco's Modified Eagle's Medium (Dulbecco's MEM, DMEM) supplemented with $10 \%$ foetal bovine serum, $2 \mathrm{mM}$ L-glutamine, 1\% MEM non-essential amino acid solution, $10 \mu \mathrm{g} / \mathrm{mL}$ gentamicin and $0.25 \mu \mathrm{g} / \mathrm{mL}$ amphotericin B. Cells were seeded in $5 \mathrm{~mL} / 25 \mathrm{~cm}^{2}$ growth media. After three to four days of growth cells were washed with phosphate buffered saline (PBS), detached with $1 \mathrm{~mL} / 25 \mathrm{~cm}^{2}$ of Hanks' balanced salt solution containing $0.05 \%$ porcine trypsin and $0.2 \mathrm{~g} / \mathrm{L}$ $\mathrm{Na}_{4}$ EDTA for $10 \mathrm{~min}$ and collected with $3 \mathrm{~mL} / 25 \mathrm{~cm}^{2}$ growth media. The cells were subcultured at $2 \times 10^{4}$ cells $/ \mathrm{cm}^{2}$ upon reaching $80 \%$ confluence. After the $19^{\text {th }}$ passage, cells were frozen in 5\% dimethyl sulfoxide in complete media in liquid nitrogen and after a fortnight thawed and seeded as described above.

\section{Cell counting}

Growth promotion was determined by counting cells using trypan blue solution and a haemocytometer. Cumulative population doublings of cells for each passage (D) was calculated using Equation 1 [25], where $\mathrm{C}=$ old passage doubling, $\mathrm{n}=$ largest natural number that satisfies equation $\mathrm{A}\left(2^{\mathrm{n}}\right) \leq \mathrm{B}, \mathrm{B}=$ number of cells counted at end of growth period and $\mathrm{A}=$ number of cells plated at the beginning of the passage. Population doubling increment was divided by the period of growth to give an average growth rate for each passage.

$$
D=C+n+\frac{B-A\left(2^{n}\right)}{A\left(2^{n+1}-2^{n}\right)} \quad \text { Equation 1) }
$$

Additionally, every second passage, cells were seeded at $8.0 \times 10^{4}$ cells/well on 12 -well plates to determine maximal growth rate and density at confluence (Table I). Growth media was changed every 3 days. After 1, 2, 3 and 6 days, cells were detached and counted on the haemocytometer. The maximal growth rate was calculated from the exponential phase of growth (days 1 - 3) for each passage and expressed as number of times population doubled in 1 day \pm SE. Density at confluence was determined after 6 days of growth. The values are presented as mean \pm SD of 4 determinations.

Table I

Protocol to determine maximal growth rate and density at confluence

\begin{tabular}{|c|c|c|c|}
\hline Step & Parameter & Value & Description \\
\hline 1 & Plate cells & $1,000 \mu \mathrm{L}$ & $\begin{array}{c}80,000 \text { HDF cells in complete media, 12-well } \\
\text { plate }\end{array}$ \\
\hline 2 & Incubation time & $24 \mathrm{~h}$ & $37^{\circ} \mathrm{C}, 5 \% \mathrm{CO}_{2}$ \\
\hline 3 & $\mathrm{Ca}^{2+}$ - and $\mathrm{Mg}^{2+}$-free Dulbecco's Phosphate Buffered Saline & $1,000 \mu \mathrm{L}$ & Wash cells \\
\hline
\end{tabular}


FARMACIA, 2019, Vol. 67, 2

\begin{tabular}{|c|c|c|c|}
\hline Step & Parameter & Value & Description \\
\hline 4 & $\begin{array}{c}0.05 \% \text { porcine trypsin, } 0.2 \mathrm{~g} / \mathrm{L} \mathrm{Na}_{4} \text { EDTA in Hanks' } \\
\text { Balanced Salt Solution }\end{array}$ & $150 \mu \mathrm{L}$ & Detach cells \\
\hline 5 & Incubation time & $20 \mathrm{~min}$ & $37^{\circ} \mathrm{C}, 5 \% \mathrm{CO}_{2}$ \\
\hline 6 & Counting cells & $\begin{array}{l}\text { At least } \\
250\end{array}$ & $\begin{array}{l}\text { Load on haemocytometer and examine under } \\
\text { the microscope }\end{array}$ \\
\hline 7 & Calculate cell density & 4 wells & \\
\hline 8 & Incubation time & $\begin{array}{c}24,48 \\
120 \mathrm{~h}\end{array}$ & $37^{\circ} \mathrm{C}, 5 \% \mathrm{CO}_{2}$ \\
\hline 9 & Repeat steps $3-7$ for all time points in 8 & 4 wells & \\
\hline
\end{tabular}

\section{Cell morphology}

The cell morphology was assessed directly from cell culture using an Evos FL (Life Technologies Carlsbad, CA, USA) inverted light microscope under the $10 \times$, $20 \times$ and $40 \times$ magnification.

Cell density and proliferation

Cell density was measured by staining cells for protein content according the sulforhodamine B (SRB) method $[26,27]$. The supernatant was removed; cells were washed with phosphate saline buffer (PBS) and fixed with a mixture of $100 \mu \mathrm{L}$ phenol red-free DMEM and $100 \mu \mathrm{L}$ cold $10 \%$ trichloroacetic acid for $1 \mathrm{~h}$ at $4^{\circ} \mathrm{C}$. Afterwards, the plate was washed with deionized water 4 times and dried completely. Fixed cells were stained with $100 \mu \mathrm{L}$ of $0.057 \%$ sulforhodamine B $(\mathrm{SRB})$ in $1 \%$ acetic acid for $30 \mathrm{~min}$ at room temperature.
The plate was washed 4 times with $1 \%$ acetic acid and then allowed to dry up completely on the bench protected from light and dust. The bound dye was solubilised with $200 \mu \mathrm{L}$ of $10 \mathrm{mM}$ Tris base ( $\mathrm{pH} 10.5)$ and the plate was shaken for $10 \mathrm{~min}$ at $200 \mathrm{rpm}$. The amount of protein in cells was determined by measuring the fluorescence of the dissolved dye at 488 and $585 \mathrm{~nm}$ as excitation and emission wavelengths, respectively, using a microplate reader $\left(\right.$ Synergy ${ }^{\text {TM }}$ HT, Bio-Tek ${ }^{\circledR}$ Instruments, VT, USA).

Cell staining and imaging for senescence-associated $\beta$-galactosidase

The percentage of senescent cells was determined for each second passage with the senescence-associated $\beta$ galactosidase (SA- $\beta$-gal) assay adopted from Tollefsbol [27] (Table II).

Table II

SA- $\beta$-gal assay protocol table

\begin{tabular}{|c|c|c|c|}
\hline Step & Parameter & Value & Description \\
\hline 1 & Plate cells & $1,000 \mu \mathrm{L}$ & $5,000 \mathrm{HDF}$ cells in complete media, 24-well plate \\
\hline 2 & Incubation time & $24 \mathrm{~h}$ & $37^{\circ} \mathrm{C}, 5 \% \mathrm{CO}_{2}$ \\
\hline 3 & $\mathrm{Ca}^{2+}$-and $\mathrm{Mg}^{2+}$-free Dulbecco's Phosphate & $1,000 \mu \mathrm{L}$ & Wash cells \\
& Buffered Saline & & Fix cells \\
\hline 4 & $3.7 \%$ formaldehyde solution & $600 \mu \mathrm{L}$ & Ambient temperature \\
\hline 5 & Incubation time & $5 \mathrm{~min}$ & $\mathrm{pH} 4.0,5.2,5.4,5.6$, each in triplicates \\
\hline 6 & Staining solution & $600 \mu \mathrm{L}$ & $37^{\circ} \mathrm{C}$, air \\
\hline 7 & Incubation time & $20 \mathrm{~h}$ & Inverted light microscope with camera \\
\hline 8 & Taken pictures with microscope & 4 images/well & inger \\
\hline
\end{tabular}

Step notes: (1) Complete media: $10 \%$ foetal bovine serum, $2 \mathrm{mM}$ L-glutamine, $1 \%$ MEM non-essential amino acid solution, $10 \mu \mathrm{g} / \mathrm{mL}$ gentamicin and $0.25 \mu \mathrm{g} / \mathrm{mL}$ amphotericin B in DMEM; (6) $\mathrm{pH} 4.0$ is control.

Fibroblasts were plated at $5.00 \times 10^{3}$ cells/well on 24 -well plates and incubated under the conditions described above. After 24 hours cells were washed with PBS, fixed with $3.7 \%$ formaldehyde solution for $5 \mathrm{~min}$ at room temperature, washed with PBS and stained with the solutions at different $\mathrm{pH}$ values. The staining solution contained $1 \mathrm{mg} / \mathrm{mL}$ X-Gal (5bromo-4-chloro-3-indolyl- $\beta$-D-galactopyranoside), $40 \mathrm{mM}$ citric acid/sodium phosphate buffer $(\mathrm{pH} 4.0$ 5.6), $5 \mathrm{mM}$ potassium ferricyanide, $5 \mathrm{mM}$ potassium ferrocyanide, $150 \mathrm{mM} \mathrm{NaCl}$ and $2 \mathrm{mM} \mathrm{MgCl}_{2}$. The well with the staining solution with $\mathrm{pH} 4.0$ served as positive control, wells with $\mathrm{pH} 5.2$ - 5.6 were used to identify senescent cells. The plate was incubated for 20 hours at $37^{\circ} \mathrm{C}$. Afterwards, several images were taken of each well using an inverted light microscope Leitz $^{\circledR}$ Type 307-148.001 (Wetzlar, Germany) with attached camera. Stained (senescent) and unstained cells were counted in wells with $\mathrm{pH}$ 5.2, 5.4 and 5.6 and the percentage of senescent cells calculated. Mitochondrial metabolism

To evaluate mitochondrial metabolism during cell culture growth, the reduction of formazan by viable mitochondria was chosen, using XTT as the substrate [26] (Table III). 
XTT and SRB assays protocol table

\begin{tabular}{|c|c|c|c|}
\hline Step & Parameter & Value & $\begin{array}{l}\text { Description } \\
\end{array}$ \\
\hline 1 & Plate cells & $100 \mu \mathrm{L}$ & $\begin{array}{l}\text { 20,000 HDF cells in double dilutions to } 156 \text { HDF cells in complete } \\
\text { media, each in } 6 \text { replicates on a 96-well plate }\end{array}$ \\
\hline 2 & Incubation time & $24 \mathrm{~h}$ & $37^{\circ} \mathrm{C}, 5 \% \mathrm{CO}_{2}$ \\
\hline 3 & $\begin{array}{l}\mathrm{Ca}^{2+} \text { - and } \mathrm{Mg}^{2+} \text {-free Dulbecco's } \\
\text { Phosphate Buffered Saline }\end{array}$ & $100 \mu \mathrm{L}$ & Wash cells \\
\hline 4 & Phenol red-free DMEM & $100 \mu \mathrm{L}$ & Added assay medium \\
\hline 5 & XTT dye solution, freshly prepared & $25 \mu \mathrm{L}$ & \\
\hline 6 & Incubation time & $4 \mathrm{~h}$ & $37^{\circ} \mathrm{C}, 5 \% \mathrm{CO}_{2}$ \\
\hline 7 & Assay readout & $450 / 630 \mathrm{~nm}$ & $\begin{array}{l}\text { Measure absorbance of reduced XTT formazan product on } \\
\text { microplate reader }\end{array}$ \\
\hline 8 & Incubation time & $16 \mathrm{~h}$ & $37^{\circ} \mathrm{C}, 5 \% \mathrm{CO}_{2}$ \\
\hline 9 & $\begin{array}{c}\mathrm{Ca}^{2+} \text { - and } \mathrm{Mg}^{2+} \text {-free Dulbecco's } \\
\text { Phosphate Buffered Saline }\end{array}$ & $100 \mu \mathrm{L}$ & Wash cells \\
\hline 10 & Cold $10 \%$ trichloroacetic acid & $100 \mu \mathrm{L}$ & Fix cells \\
\hline 11 & Incubation time & $60 \mathrm{~min}$ & $4^{\circ} \mathrm{C}$ \\
\hline 12 & Cold deionised water & $4 \mathrm{x}$ & Wash cells \\
\hline 13 & Dry & $24 \mathrm{~h}$ & Ambient temperature \\
\hline 14 & SRB staining solution & $100 \mu \mathrm{L}$ & Mix $10 \mathrm{~s}$ \\
\hline 15 & Incubation time & $60 \mathrm{~min}$ & Ambient temperature \\
\hline 16 & $1 \%$ acetic acid & $4 x$ & Remove unbound SRB \\
\hline 17 & Dry & $24 \mathrm{~h}$ & Ambient temperature \\
\hline 18 & $10 \mathrm{mM}$ Tris base, $\mathrm{pH} 10.5$ & $200 \mu \mathrm{L}$ & Solubilise bound SRB; 200 rpm, 5 min \\
\hline 19 & Assay readout & $488 / 585 \mathrm{~nm}$ & Measure fluorescence of SRB on microplate reader \\
\hline
\end{tabular}

Step notes: (1) Complete media: 10\% foetal bovine serum, $2 \mathrm{mM} \mathrm{L}$-glutamine, $1 \%$ MEM non-essential amino acid solution, $10 \mu \mathrm{g} / \mathrm{mL}$ gentamicin and $0.25 \mu \mathrm{g} / \mathrm{mL}$ amphotericin B in DMEM; (4) Blanks: to 6 empty wells; (5) Composition of the XTT dye solution presented in text; (7) $450 \mathrm{~nm}$ test wavelength, $630 \mathrm{~nm}$ reference wavelength; (14) Composition of SRB staining solution presented in text.

Cells were plated at densities $0.16-20.0 \times 10^{3}$ cells/ well under the conditions described above. After 24 hours of incubation cells were washed with PBS and $100 \mu \mathrm{L}$ phenol red-free DMEM supplemented with $10 \mu \mathrm{g} / \mathrm{mL}$ gentamicin and $0.25 \mu \mathrm{g} / \mathrm{mL}$ amphotericin $\mathrm{B}$ was added to reduce interference of red coloured $\mathrm{pH}$ indicator with absorbance measurements of orangecoloured formazan product of XTT reduction. $25 \mu \mathrm{L}$ XTT dye solution comprised of $1 \mathrm{mg} / \mathrm{mL}$ XTT and $25 \mu \mathrm{M}$ phenazine methosulfate in phenol red-free DMEM was added to each well. After 4 hours of incubation, the absorbance was read at $450 \mathrm{~nm}$ and $630 \mathrm{~nm}$ as test and reference wavelengths, respectively, using a microplate reader (Synergy ${ }^{\mathrm{TM}} \mathrm{HT}$, Bio-Tek ${ }^{\circledR}$ Instruments, VT, USA).

Data analysis

The maximal growth rate was calculated from the linear phase of growth. Cell density (Ln) was plotted against days of growth for each second passage and linear regression was made from day 1 to day 3 . The slope represents the maximal growth rate expressed as population doublings per day ( $\mathrm{PDL} /$ day). The maximal growth rate and density at confluence for early passages were calculated as mean \pm SD for passages 5,7 and 9. Response curves for XTT and SRB assays were determined by linear regression through points for plating densities $6.25-10.0 \times 10^{3}$ cell/well. For comparison between passages absorbance or fluorescence intensity, it was calculated for theoretical plating density $5.00 \times 10^{3}$ cell/well using the obtained response curves. The statistical significance of all trends was tested with linear regression analysis. Slope coefficients were expressed as confidence intervals. The confidence level was set to $95 \%$. All statistical tests were conducted with the StatPlus:mac LE (Version v5), AnalystSoft Inc., Walnut, CA, USA software package for Microsoft Excel.

\section{Results and Discussion}

In our study, in vivo aged HDF from a 67-year old female donor were monitored during the first 35 passages for the characteristics found in cells of older people, such as slower proliferation rate, pronounced contact inhibition and propagation of senescent cells compared with healthy adult cells. As shown in Figure 1, cells in middle and late passages were larger, but sparser than those in early passages, and with more prominent organelles. Additionally, cells in early passages are almost exclusively bipolar, thin and spindle-shaped. As they age in the culture they widen and outgrowths become more frequent. 
FARMACIA, 2019, Vol. 67, 2
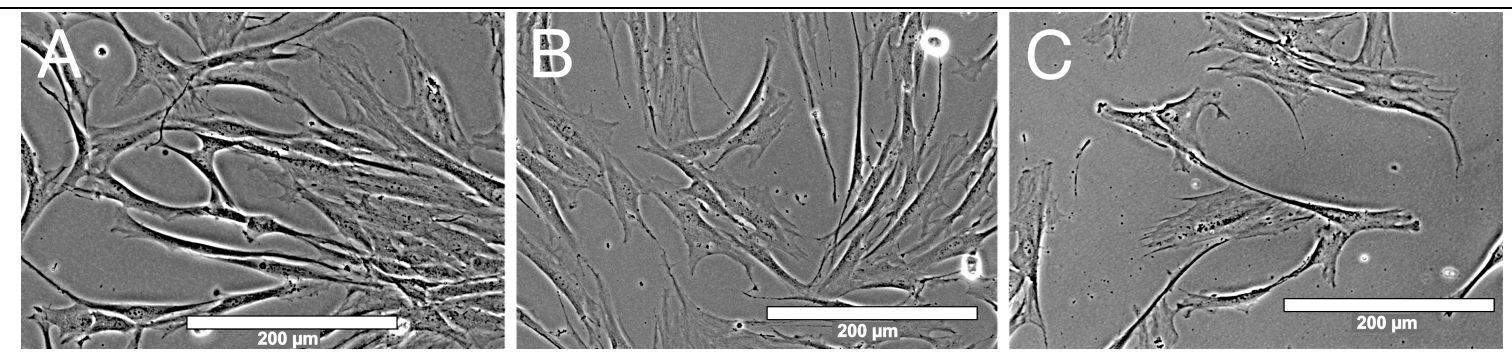

Figure 1.

Age-related changes in morphology of human dermal fibroblasts. Cells in passage 2 (A) are spindle-shaped and abundant. In passage 19 (B) some cells are wider and with outgrowths and in passage 35 (C) cells become as wide as long, with many outgrowths and are sparse. Scale bar represents $200 \mu \mathrm{m}$

Maximal cellular growth rate in early passages (passages 5 - 10) was $24 \pm 2 \mathrm{~h}$ per population doubling and density at confluence was $7.7 \pm 1.7 \times 10^{4}$ cells $/ \mathrm{cm}^{2}$, which coincides with reported values for cells of older donors [16]. However, the average growth rate and density at confluence decreased $(\mathrm{p}<0.001$ and $\mathrm{p}=$ $0.003)$ with the in vitro age of the culture. The drop in the course of 35 passages was approximately 4and 3 -fold, respectively (Figure 2).

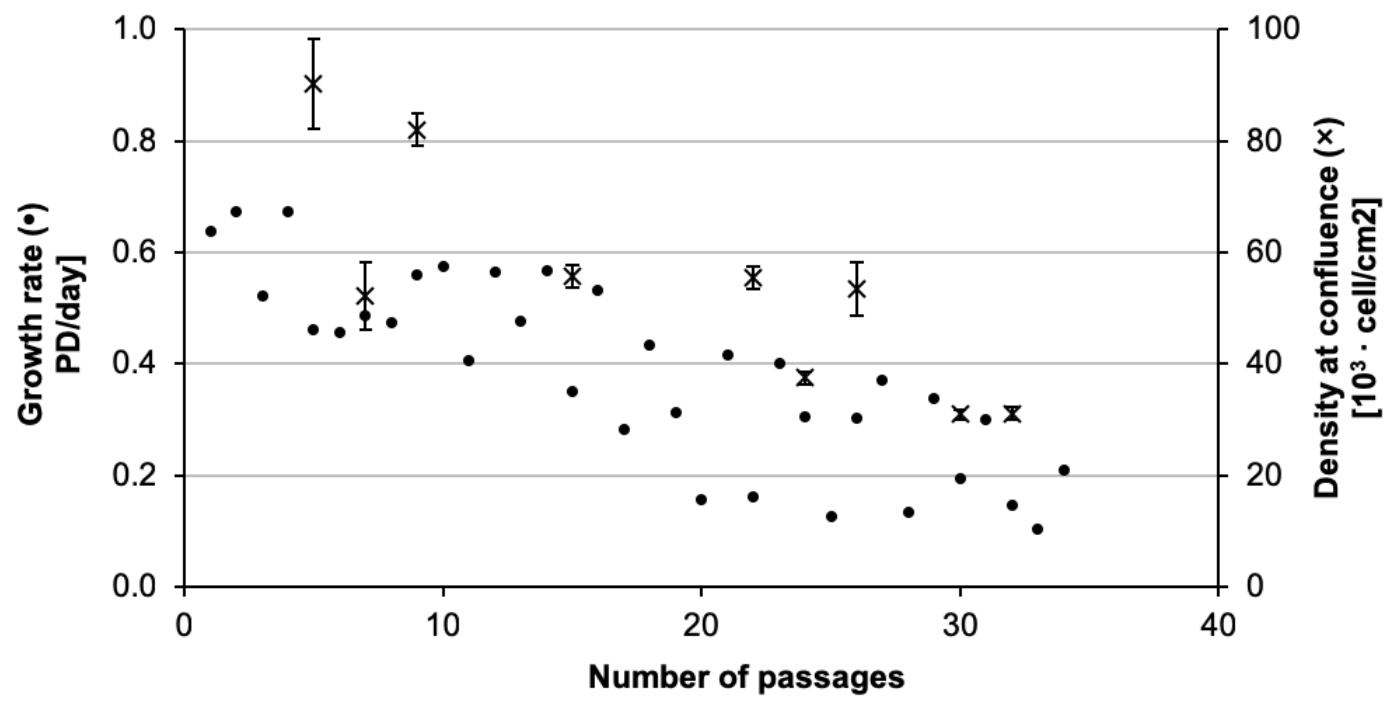

Figure 2.

Two cell culture growth characteristics for first 35 passages of human dermal fibroblasts. Average growth rate

$(\bullet)$ decreased at rate $0.014 \pm 0.003 \mathrm{PDL} /$ day/passage. Density at confluence (x), presented as mean $\pm \mathrm{SD}$ of quadruplicate wells $(\mathrm{n}=4)$ (values with RSD above $15 \%$ were omitted from the graph and calculations), decreased at rate $1.70 \pm 1.01 \times 10^{3} \mathrm{cell} / \mathrm{cm}^{2} /$ passage. Slopes were obtained by linear regression and confidence intervals were calculated at $95 \%$ confidence level

Senescent cells were detected by the overexpression of senescence-associated $\beta$-galactosidase. The optimal $\mathrm{pH}$ for aged HDFs at which only senescent cells stained was 5.2 - 5.6. At lower $\mathrm{pH}$, all cells stained, and at higher $\mathrm{pH}$ values, no cells coloured in blue. Senescent cells emerged continuously and steadily $(p=0.003$ ) from 0 to $20 \%$ during the observation period of the first 35 passages.

The linear range coinciding in both the XTT and SRB assays was $2-30 \times 10^{3}$ cell $/ \mathrm{cm}^{2}$. The half maximal highest seeding density was chosen for evaluation to detect minimal declines in cell viability whilst being able to accurately determine boosts in viability. In the course of 15 passages, the metabolic activity of aged HDF declined $(p=0.003)$ for $75 \%$. After freezing and thawing at passage 15, cells' reduction ability increased to the early passage level and decreased $(\mathrm{p}=0.002)$ with the similar rate as before. Cellular protein content more than doubled $(\mathrm{p}<0.001)$ from the initial $0.5 \mathrm{ng} / \mathrm{cell}$, a typical value for all human fibroblasts, regardless of in vivo age [16], and was unaffected by freeze-thawing the cells (Figure 3). 
FARMACIA, 2019, Vol. 67, 2

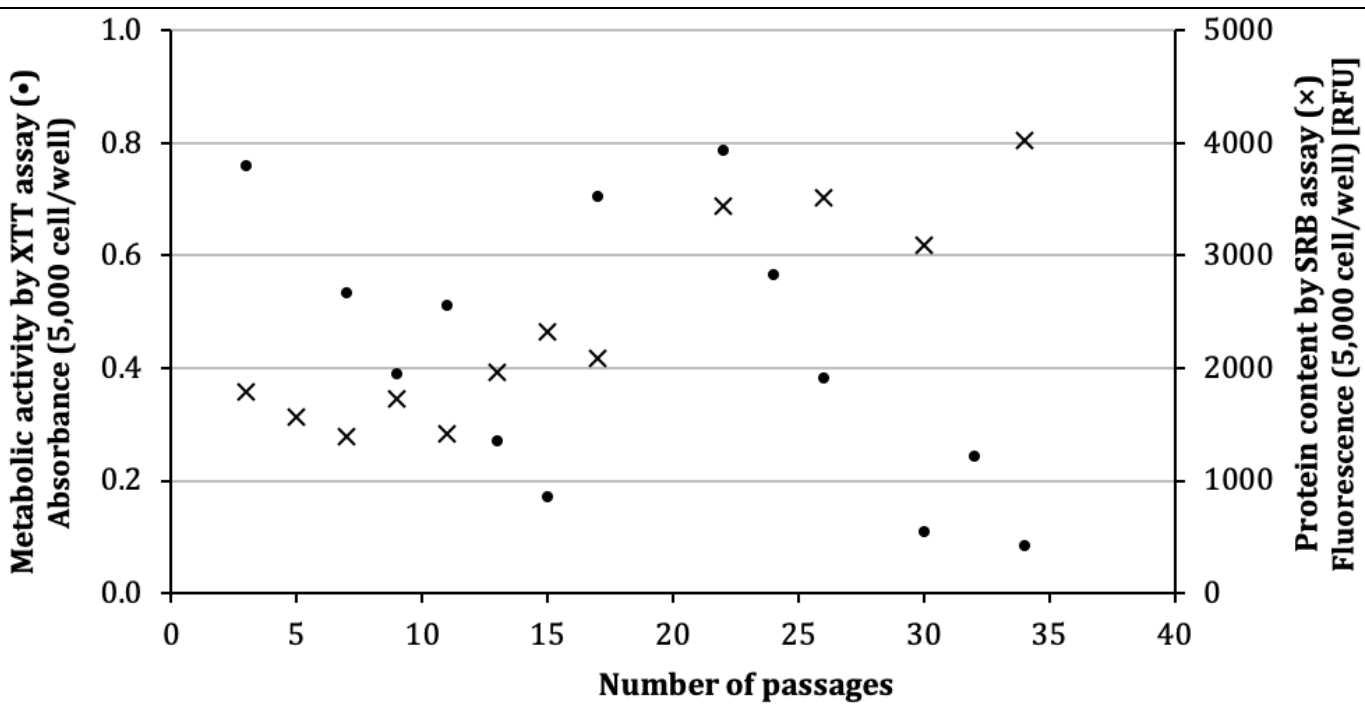

Figure 3.

Cell viability of human dermal fibroblasts as a function of the number of cell passages. Relative metabolic activity, measured by the XTT assay, decreased at similar rate before freezing (passages $3-15,0.046 \pm$ 0.022 passage) and after thawing (passages $17-35,0.043 \pm 0.022 /$ passage). Relative protein content, measured by the SRB assay increased at rate $84 \pm 25 \mathrm{RFU} /$ passage and freeze-thaw cycle did not have any impact. Values represent calculated fluorescence or absorbance for 5,000 cell/well from XTT (•) and SRB ( ) response curves, respectively, for each passage. Slopes were obtained by linear regression and confidence intervals were calculated at $95 \%$ confidence level

Researchers have shown that the in vitro artificially aged culture model is appropriate for cell ageing research [15, 16, 28, 29]. Nevertheless, scientists are in favour of exploiting cells that have been originally aged in vivo, because growth conditions in culture differ from those in the living tissues considerably $[15,16,26,30]$. Accordingly, cells from a donor aged 65 years old or more were chosen for this "naturally" aged cell culture model. This approach is also more efficient with regard to time and resources needed to age cells in artificial setting. In our study HDFs from a female Asian 67-year-old donor were identified as an appropriate aged cell culture model. All examined signs of ageing were in accordance with the expectations for in vivo aged fibroblasts. Senescent cells, as one of the markers of skin functionality impairment, were scarce in the first passages. Deficiency of senescent cells in very early passages is believed to be due to the cell extraction process from the tissue where only proliferating cells survive. Therefore, the senescence observed in the present study may be caused by stress introduced through in vitro culturing. However, since senescent cells are found in skin tissues of elderly donors [31], we believe the cell culture expressing senescent phenotype to the similar degree as in vivo aged cells represent a more reliable geriatric cell culture model. In order to confirm these findings, further research using additional markers for ageing such as telomere length or mitochondrial age are required.

As the number of passages increases, cells adapt to the in vitro conditions and no longer resemble their in vivo state. Altered shape, increased protein content, slower proliferation and lower metabolic activity were detected over time in this study. Thus, passages 5 10 of aged human dermal fibroblasts were found to mimic in vivo tissue of older adults to the greatest extent: senescent cells are consistently found in those passages at approximately 5\% level, while none of the observed characteristics changed significantly during the first 10 passages (growth rate: $p=0.087$, density at confluence: $p=0.434$, metabolic activity: $\mathrm{p}=0.064$, protein content: $\mathrm{p}=0.186$ ).

Moreover, Shen et al. [31] showed approximately 3 -fold difference in viability and 2 -fold difference in SA- $\beta$-gal expression between HDFs from young (22 years) and old (65 years) volunteers in similar passages. This suggests there is a vast difference between young and in vivo aged cells and highlights the need for a cell culture model that represents the population of interest. Furthermore, permeability of human endothelial cells increases as they age in culture or in tissue. This is partly due to the increased number of senescent cells leading to leaky junctions $[18,32]$. This knowledge further strengthens the rationale to test novel drug delivery systems for older patients on an aged cell culture model.

An important finding, and potential source of errors was that freeze-thaw cycles apparently reset cellular metabolic activity to the level of passage 0 , although not affecting protein content and other parameters (growth rate, density at confluence and \% senescent cells). Therefore, the robust and reproducible SRB assay is recommended for cell proliferation measurements 
FARMACIA, 2019, Vol. 67, 2

rather than the formazan-based assays, which measure metabolic activity only. If metabolic activity is not important for the study, then freeze-thaw cycles may be allowed.

The presented methodology may serve as a basis for the preclinical assessment of safety and effectiveness of drugs alone or their delivery systems developed for geriatric populations. Both the selected cell line and the methods used are widely accessible and affordable, thus offering a robust and comparable culture for such protocols. Aged cell culture method holds promise in helping the pharmaceutical research to develop drug delivery systems tailored considering the age related physiological changes. In our future work, we will aim to provide a proof of the presented concept, for example by incubating young and old cell culture with a drug that is known to be absorbed at decreased rate with advancing age [33].

\section{Conclusions}

We provide here a standardised cell culture protocol of naturally aged ( $>65$ years old) human dermal fibroblasts, which has application in the screening of drug delivery systems intended for geriatric patients. The protocol was characterised by the evolution of ageing parameters based on morphology, proliferation rate, mitochondrial metabolic activity, cell protein content and the senescence marker SA- $\beta$-gal. Passages 5 - 10 of our selected aged human dermal fibroblasts were found to mimic in vivo tissue of older adults to the greatest extent and therefore in vitro tests must be performed within these limits for the results to be more relevant to geriatric patients.

\section{References}

1. Wahlich J, Stegemann S, Orlu-Gul M, Meeting commentary "medicines for older adults: learning from practice to develop patient centric drug products". Int J Pharm., 2013; 456(1): 251-257.

2. Wehling M, Drug Therapy for the Elderly. Springer Science \& Business Media, 2013.

3. Perrie Y, Badhan RK, Kirby DJ, Lowry D, Mohammed AR, Ouyang D, The impact of ageing on the barriers to drug delivery. $J$ Control Release, 2012; 161(2): 389-398.

4. Aleksovski A, Dreu R, Gasperlin M, Planinsek O, Mini-tablets: a contemporary system for oral drug delivery in targeted patient groups. Expert Opin Drug Deliv., 2015; 12(1): 65-84.

5. Itoh K, Hatakeyama T, Shimoyama T, Miyazaki S, D'Emanuele A, Attwood D, In situ gelling formulation based on methylcellulose/pectin system for oralsustained drug delivery to dysphagic patients. Drug Dev Ind Pharm., 2011; 37(7): 790-797.

6. Parkash V, Maan S, Deepika, Yadav SK, Hemlata, Jogpal V, Fast disintegrating tablets: Opportunity in drug delivery system. $J$ Adv Pharm Technol Res., 2011; 2(4): 223-235.
7. Scarpa M, Stegemann S, Hsiao WK, Pichler H, Gaisford S, Bresciani M, Paudel A, Orlu M, Orodispersible films: Towards drug delivery in special populations. Int $J$ Pharmaceut., 2017; 523(1): 327-335.

8. Nolte DD, An R, Turek J, Jeong K, Tissue dynamics spectroscopy for phenotypic profiling of drug effects in three-dimensional culture. Biomedical Optics Express, 2012; 3(11): 2825-2841.

9. Sun H, Merrill D, An R, Turek J, Matei D, Nolte $\mathrm{DD}$, Biodynamic imaging for phenotypic profiling of three-dimensional tissue culture. J Biomed Optics, 2017; 22(1): 1-10.

10. Meijer TG, Naipal KAT, Jager A, van Gent DC, $E x$ vivo tumor culture systems for functional drug testing and therapy response prediction. Future Sci OA., 2017; 3(2): 1-13.

11. Hayflick L, Moorhead PS, The serial cultivation of human diploid cell strains. Exp Cell Res., 1961; 25: 585-621.

12. Sikora E, Arendt T, Bennett M, Narita M, Impact of cellular senescence signature on ageing research. Age Res Rev., 2011; 10(1): 146-152.

13. Magalhães JP, From cells to ageing: a review of models and mechanisms of cellular senescence and their impact on human ageing. Exp Cell Res., 2004; 300(1): 1-10.

14. Naylor RM, Baker DJ, van Deursen JM, Senescent cells: a novel therapeutic target for aging and agerelated diseases. Clin Pharmacol Ther., 2013; 93(1): 105-116.

15. Tigges J, Krutmann J, Fritsche E, Haendeler J, Schaal H, Fischer JW, Kalfalah F, Reinke H, Reifenberger G, Stühler K, Ventura N, Gundermann S, Boukamp P, Boege F, The hallmarks of fibroblast ageing. Mech Age Develop., 2014; 138: 26-44.

16. Schneider EL, Mitsui Y, The relationship between in vitro cellular aging and in vivo human age. Proceed Nat Acad Sci USA, 1976; 73(10): 3584-3588.

17. Macieira-Coelho A, Behavior of cells in culture and physiopathology of organism. In: Biology of Normal Proliferating Cells in vitro (von Hahn HP, ed.), pp. 6-20. Karger, Basel, Switzerland, 1988.

18. Childs BG, Durik M, Baker DJ, Deursen JMv, Cellular senescence in aging and age-related disease: from mechanisms to therapy. Nat Med., 2015; 21: 1424-1435.

19. Campisi J, Senescent cells, tumor suppression, and organismal aging: good citizens, bad neighbors. Cell, 2005; 120(4): 513-522.

20. Human Primary Cells. www.lgcstandards-atcc.org.

21. Yuan Q, Fu Y, Kao WJ, Janigro D, Yang H, Transbuccal delivery of CNS therapeutic nanoparticles: Synthesis, characterization, and in vitro permeation studies. ACS Chem Neurosci., 2011; 2(11): 676-683.

22. Gao W, Lai JCK, Leung SW, Functional enhancement of chitosan and nanoparticles in cell culture, tissue engineering, and pharmaceutical applications. Frontiers in Physiololgy, 2012; 3: 1-13.

23. Abercrombie M, Fibroblasts. J Clin Path., 1978; 31(12): 1-6.

24. Rittié L, Fisher GJ, Isolation and Culture of Skin Fibroblasts. Meth Mol Med., 2014; 117: 83-98. 
25. Phipps SMO, Berletch JB, Andrews LG, Tollefsbol TO, Aging cell culture: Methods and observations. Meth Mol Biol., 2007; 371: 9-19.

26. Roehm NW, Rodgers GH, Hatfield SM, Glasebrook $\mathrm{AL}, \mathrm{An}$ improved colorimetric assay for cell proliferation and viability utilizing the tetrazolium salt XTT. J Immunol Met., 1991; 142(2): 257-265.

27. Vichai V, Kirtikara K, Sulforhodamine B colorimetric assay for cytotoxicity screening. Nat Protoc., 2006; 1(3): 1112-1116.

28. Rubin $\mathrm{H}$, Cell aging in vivo and in vitro. Mech Ageing Develop., 1997; 98(1): 1-35.

29. Boisen L, Drasbek KR, Pedersen AS, Kristensen P, Evaluation of endothelial cell culture as a model system of vascular ageing. Exp Geront., 2010; 45(10): 779-787.

30. Dimri GP, Lee X, Basile G, Acosta M, Scott G, Roskelley C, Medrano EE, Linskens M, Rubelj I,
Pereira-Smith O, Peacocke M, Campisi J, A biomarker that identifies senescent human cells in culture and in aging skin in vivo. Cell Biology, 1995; 92(20): 9363-9367.

31. Shen X, Du Y, Shen W, Xue B, Zhao Y, Adiposederived stem cells promote human dermal fibroblast function and increase senescence-associated $\beta$ galactosidase mRNA expression through paracrine effects. Mol Med Rep., 2016; 10(6): 3068-3072.

32. Cheung TM, Ganatra MP, Peters EB, Truskey GA, Effect of cellular senescence on the albumin permeability of blood-derived endothelial cells. $\mathrm{Am}$ J Physiol Heart Circ Physiol., 2012; 303(11): H1374-H1383.

33. Bender $\mathrm{AD}$, Effect of age on intestinal absorption: Implications for drug absorption in the elderly. $J$ Am Geriat Soc., 1968; 16(12): 1331-1339. 